\title{
PELATIHAN EMPATI UNTUK MENURUNKAN PERILAKU BULLYING PADA PELAKU BULLYING DI SEKOLAH DASAR
}

\author{
Lailatul Izzah' \\ Program Studi Psikologi Islam, STAI Diniyah Pekanbaru \\ Sukarti \\ Uly Gusniarti² \\ Fakultas Psikologi dan Ilmu Sosial Budaya Universitas Islam Indonesia
}

\begin{abstract}
This study aims to determine the effect of empathy training to reduce bullying behavior on the offender bullying in primary school. Subjects in this study were 10-11 years old who have low and medium empathy scores nor high and medium bullying behavior. There were eight students who become participants in this study. The data were collected by using interview, observation, peer relations questionaires, bullying scales, and empathy scales. This study was using one group pretest-posttest design. The data were analyzed by using quantitative analysis of two related sample test by Wilcoxon. The results showed that empathy scores ( $Z=-2.52$, $p=0.012(p<0.05))$ and bullying scores $(Z=-2.207, p=0.027(p<0.05))$ underwent a significant change pretest-posttest. Meanwhile, empathy scores $Z=-1.452, p=0.146(p>0.05))$ and bullying scores ( $Z=-1.897, p=0.058(p>0.05)$ ) had no significant changes posttest- follow up. Furthermore, empathy scores $(Z=-2.530, p=0.011(p<0.05))$ and bullying scores $(Z=-2.533, p=0.011(p<0.05))$ underwent a significant change pretest-follow-up.
\end{abstract}

Keywords: Bullying Behavior, Elementary School. Empathy Training,

\begin{abstract}
ABSTRAK: Penelitian ini bertujuan mengetahui pengaruh pelatihan empati terhadap perilaku bullying pada pelaku bullying di sekolah dasar. Subjek dalam penelitian ini berusia 10-11 tahun yang memiliki skor empati pada tingkat rendah dan sedang atau perilaku bullying pada tingkat tinggi dan sedang. Ada delapan siswa peserta penelitian ini. Pengumpulan data menggunakan wawancara, observasi, kuesioner, skala bullying, dan skala empati. Penelitian ini menggunakan one group pretest-posttest design. Data dianalisis secara kuantitatif two related sample test Wilcoxon. Hasil penelitian menunjukkan skor empati $(\mathrm{Z}=-2,52, \mathrm{p}=0,012$ $(\mathrm{p}<0,05))$ dan skor bullying $(\mathrm{Z}=-2,207, \mathrm{p}=0,027(\mathrm{p}<0,05))$ ada perbedaan antara pratespascates. Sementara itu, skor empati $(Z=-1,452, p=0,146(p>0,05))$ dan skor bullying $(Z=-$ $1,897, p=0,058(p>0,05))$ tiak ada perbedaan antara pascates-tindaklanjut. Selanjutnya, skor empati $(\mathrm{Z}=-2.530, \mathrm{p}=0,011(\mathrm{p}<0,05))$ dan skor bullying $(\mathrm{Z}=-2,533, \mathrm{p}=0,011(\mathrm{p}<0,05))$ ada perbedaan antara prates-tindaklanjut.
\end{abstract}

Kata kunci: Pelatihan Empati, Perilaku Bullying, Sekolah Dasar

\footnotetext{
${ }^{1}$ Koresponden mengenai artikel dapat melalui: zhalaila14@gmail.com

2 uly gusniarti@yahoo.com
} 
Saat ini fakta yang marak terjadi di media massa seperti televisi, majalah, maupun koran adalah kasus kekerasan di lingkungan masyarakat yang merajalela, hal ini juga terjadi di sekolah. Sekolah yang merupakan tempat untuk menimba ilmu menjadi tempat yang cukup berbahaya bagi anak-anak apabila ragam kekerasan tidak segera diantisipasi, seperti aksi bullying yang terjadi pada siswa SDN 023 Pajagalan, kota Bandung yang sempat viral di media sosial. Korban dikeroyok, dipegangi oleh murid lainnya, tak hanya dimaki dengan kata-kata kasar, namun juga dipukul (Tribunnews.com, 2019)

Data yang diperoleh dari National Center for Educational Statistic of America pada tahun 2013, didapat bahwa 27,8\% siswa melakukan bullying selama di sekolah (Megan Mier Foundation, 2014). Komisi Perlindungan Anak Indonesia (KPAI) menyebutkan dari tahun 2011 sampai Agustus 2014 tercatat 1.480 kasus bullying yang terjadi di sekolah (KPAI, 2014)

Berdasarkan hasil studi pendahulan oleh peneliti melalui observasi dan wawancara di sekolah dasar " $X$ " di kota Yogyakarta, didapatkan data bahwa ditemukan tindakan bullying yang dilakukan siswa terhadap temannya. menurut guru wali kelas dan guru yang mengajar di kelas 4A tersebut terdapat 3 orang siswa di kelas 4A yang sering melakukan bullying kepada siswa lain. kemudian peneliti menyebarkan sosiometri kepada siswa kelas 4A untuk menjaring siswa yang sering melakukan bullying kepada siswa lain dan diperoleh 9 siswa yang memiliki skor tertinggi dari 27 siswa di kelas 4A. Beberapa siswa tersebut melakukan bullying secara fisik dan psikis. Bullying secara fisik Nampak pada beberapa kejadian seperti: siswa memukul, menendang, mendorong badan dan kepala temannya, menarik kuping temannya, mengancam melalui gestur (melotot, simbolsimbol tangan) dan memalak. Bullying secara psikis terlihat pada beberapa kejadian seperti: siswa berkata kotor dan kasar pada saat ia tersinggung, emosi dan juga untuk memaki temannya, bahkan dalam keadaan normal pun kata-kata kotor dan kasar ini sering dipergunakan. Siswa juga mengejek temannya, mengancam temannya jika temannya akan mengadukan perbuatannya kepada guru atau jika tidak melakukan sesuatu yang diperintahkan. Selain itu terdapat juga siswa yang menghasut teman-temannya untuk menjauhi dan memusuhi salah seorang siswa sehingga ia tidak memiliki teman.

Observasi juga dilakukan pada setting belajar mengajar di kelas. Bullying secara psikis bahkan juga dilakukan siswa terhadap guru wali kelas. Siswa tidak lagi merasa takut ataupun segan terhadap guru tersebut. Siswa berani menggunakan kata-kata kasar, suara lebih tinggi dari guru, mengumpat dan juga membuat gaduh untuk menunjukkan rasa tidak senangnya terhadap guru tersebut. Siswa pun membuat suasana pembelajaran menjadi tidak kondusif. Siswa akan melempar-lempar kertas kearah temannya, berjalan-jalan ketika guru sedang menjelaskan pelajaran, berbicara kurang sopan dengan guru, serta menjawab pertanyaan dari guru dengan seenaknya sendiri.

Melihat permasalahan di atas, peneliti tertarik untuk melakukan penelitian tentang bullying pada siswa. Hal yang demikian dikarenakan tindak kekerasan (bullying) dapat memberikan dampak yang negatif untuk jangka waktu yang pendek dan panjang. Selain itu, perilaku-perilaku demikian dirasakan mengganggu baik oleh siswa (yang menjadi korban dan siswa yang hanya menyaksikannya) maupun oleh guru.

Menurut Olweus dan Limber (2007) bullying ialah ketika seseorang melakukan tindakan menyakiti orang lain secara berulang. terdapat tiga unsur mendasar perilaku bullying, yaitu: (1) bersifat menyerang dan negatif, (2) Ddlakukan secara berulang kali; dan (3) adanya 
ketidakseimbangan kekuatan antara pihak yang terlibat. Bullying memiliki dua sub-tipe bullying, yaitu perilaku secara langsung (direct bullying), misalnya penyerangan secara fisik dan perilaku secara tidak langsung (indirect bullying), misalnya pengucilan secara sosial.

Berdasarkan penelitian Assegaf tahun 2002 (dalam Efianingrum, 2009) bullying dalam pendidikan bisa diakibatkan buruknya sistem dan kebijakan pendidikan yang berlaku, misalnya muatan kurikulum yang hanya mengandalkan kemampuan aspek kognitif dan mengabaikan aspek afektif, yang menyebabkan berkurangnya proses humanisasi dalam pendidikan, seperti siswa menjadi tidak peka terhadap perasaan maupun keadaan orang disekitarnya. Berdasarkan wawancara dengan wali kelas, guru yang mengajar di kelas 4A dan kepala sekolah SD " $\mathrm{X}$ " pada tanggal 08 dan 09 Desember 2016 pukul 09.50 di ruang kepala sekolah dan ruang guru, guru mengatakan bahwa pelajaran tentang merasakan apa yang orang lain rasakan (empati) kepada siswa hanya diajarkan pada saat ada kejadian perkelahian, siswa terlibat pertengkaran, memukul, menendang dan mengejek temannya secara berulang setiap hari. Sementara, belum ada mata pelajaran khusus yang membahas empati untuk siswa. Guru biasanya hanya memberikan nasehat sebelum memulai pelajaran. Wali kelas juga mengatakan bahwa siswa sering terlihat senang sesaat setelah memukul, menendang atau menyakiti temannya, dan baru akan membantu temannya setelah diperintah guru.

Selain wawancara, juga dilakukan pengamatan selama pelajaran berlangsung dan ketika istirahat pada tanggal 9, 10 dan 11 Desember 2015, dan didapatkan data bahwa siswa yang melakukan perilaku agresif atau bullying kepada temannya terlihat senang melihat temannya dipukul, sementara teman yang malah ikut tertawa, saat teman diberi hukuman, 2 orang siswa mengejek-ejek temannya. Adanya fenomena yang lain adalah siswa yang tidak mau meminjamkan pena saat temannya tidak membawa pena serta mentertawakan dan menyoraki saat olahraga ada siswa lain yang terjatuh karena tersandung batu. Hal ini menunjukkan bahwa empati belum benarbenar tertanam pada siswa karena muatan kurikulum yang hanya mengandalkan aspek kognitif. Oleh karena itu, siswa menjadi kurang peka terhadap perasaan maupun keadaan orang lain.

Tindakan kekerasan yang dilakukan anak merupakan wujud dari agresi (Baron\&Byrne, 2005). Salah satu faktor penyebab agresi adalah hilangnya empati pada korban (Baron\&Byrne, 2005; Carr \& Lutjemeier, 2005; Passer \& Smith, 2007). Lovett dan Sheffield (2007) mengupas 17 penelitian mengenai hubungan antara agresi dengan hilangnya empati, anak yang memiliki empati yang rendah akan cenderung agresif.

Berdasarkan fenomena hasil studi pendahuluan serta studi literatur yang dilakukan maka penelitian ini fokus terhadap pelatihan meningkatkan empati yang ditujukan untuk meningkatkan kemampuan bereaksi terhadap perasaan orang lain dengan suatu respons emosional yang sama dengan perasaan-perasaan orang lain (empati). Dengan ditumbuhkannya kemampuan empati, diharapkan pelaku bullying menjadi lebih mampu merasakan emosi dari orang yang menjadi korban tindakan bullying yang dilakukannya. Dengan memahami emosi dan ikut merasakan apa yang dirasakan jika ia menjadi korban bullying, diharapkan pelaku tidak lagi memiliki niat untuk melakukan tindakan bullying kepada orang lain dengan menumbuhkan empati dalam diri pelaku terhadap situasi yang dapat merugikan orang lain.

Hipotesis penelitian ini ialah ada pengaruh pelatihan dalam meningkatkan 
empati yang diberikan untuk mengurangi perilaku bullying pada pelaku bullying dan ada perubahan peningkatan empati dan penurunan perilaku bullying sebelum, setelah dan follow-up.

\section{METODE PENELITIAN}

\section{Subjek Penelitian}

Subjek penelitian ini adalah siswa kelas 4A SDIT "X" Yogyakarta berjumlah 8 orang. Teknik pengambilan sampel yang digunakan dalam penelitian ini adalah purposive sampling non random sampling yaitu kelas $4 \mathrm{~A}$ yang berjumlah 26 orang. Peneliti mempertimbangkan karakteristikkarakteristik tertentu dalam melakukan penyeleksian yang akan dijadikan subjek.
Adapun karakteristik subjek yang digunakan dalam penelitian ini adalah: (1) Siswa SDIT "X" Yogyakarta kelas 4A; (2) Jenis kelamin laki-laki; (3) Usia 10-11 tahun; (4) Siswa yang teridentifikasi sebagai pelaku bullying dengan menggunakan peer relations questionnaire (PRQ); (5) Memiliki skor bullying yang tinggi dan sedang, yang diukur dengan skala perilaku bullying (pretest); (6) Memiliki skor empati yang rendah dan sedang, yang diukur dengan skala empati (pretest); (7) Subjek bersedia untuk mengikuti seluruh rangkaian penelitian eksperimen yang terdiri dari pretest (pengisian skala empati dan bullying), mengikuti pelatihan meningkatkan empati, posttest dan follow-up (pengisian skala empati dan bullying).

\begin{tabular}{cccccc}
\hline Insial & Usia & Skor Empati & K & Skor Bullying & K \\
\hline HM & 10 th & 8 & Rendah & 20 & Tinggi \\
\hline HN & 10 th & 8 & Rendah & 24 & Tinggi \\
\hline AZ & 10 th & 16 & Sedang & 13 & Sedang \\
\hline ML & 10 th & 15 & Sedang & 12 & Sedang \\
\hline LF & 10 th & 6 & Rendah & 14 & Sedang \\
\hline DR & 10 th & 10 & Rendah & 13 & Sedang \\
\hline SA & 10 th & 9 & Rendah & 13 & Sedang \\
\hline AD & 10 th & 8 & Rendah & 10 & Sedang \\
\hline
\end{tabular}

\section{Desain Penelitian}

Desain dalam penelitian ini berupa one group pretest and posttest design (Shadis, Cook \& Campbell, 2002). Dalam one grup pretest-posttest, kegiatan di dalamnya akan dikontrol oleh kondisi sebelum dan sesudah evaluasi. Setelah pemberian perlakuan, akan dilakukan follow-up untuk mengetahui efek pelatihan meningkatkan empati terhadap subjek penelitian setelah jangka waktu tertentu. Desain penelitian dapat digambarkan seperti gambar berikut:

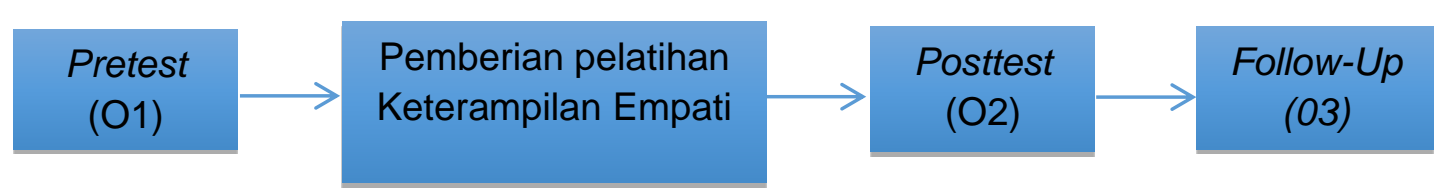

Gambar 1. Desain Penelitian

Sebelum program dimulai, peneliti menyebarkan angket sosiometri peer relations quationnaire (PQR) (Sidorowics. $\mathrm{K}$, Elizabet, dkk (2009) untuk menjaring pelaku bullying. Setelah diperoleh beberapa pelaku siswa kemudian diberi kuesioner dan checklist behavior untuk melihat empati dan perilaku bullying. Setelah melakukan prates, 
siswa mendapatkan pelatihan meningkatkan empati untuk mengurangi perilaku bullying.

\section{Prosedur Intervensi}

a. Melakukan prates berupa skala empati dan bullying serta observasi pada 8 subjek telah di screening dengan menggunakan peer relations questionnaire (PRQ), skala bullying dan empati dengan tujuan untuk mengetahui hasil awal skor empati dan bullying subjek sebelum diberi perlakuan pada tanggal 16-18 Februari 2016. Selanjutnya, Observasi perilaku anak dilakukan selama 3 hari dengan 2 sesi pengamatan. Pelaksanaan prates dilakukan pada tanggal 16-18 Februari 2016. Setiap hari observer mengobservasi 1 sesi pengamatan pada 2 jam pelajaran yaitu tujuh puluh lima menit (75 menit). Satu sesi pengamatan lagi dilakukan pada setting alami saat anak berinteraksi dengan temannya dilingkungan sekolah (Istirahat). Skor perilaku bullying dan empati anak dalam satu hari pengamatan didapat dengan cara mencari kesepakatan angka perilaku bullying dan empati dari 2 orang observer terhadap anak yang diamati.

b. Pembekalan fasilitator

Pelatihan meningkatkan empati diberikan seorang fasilitator, yakni Psikolog yang memiliki latar belakang pendidikan dengan konsentrasi psikologi pendidikan, mempunyai pengalaman mengikuti suatu pelatihan, workshop, seminar dan pertemuan ilmiah lainnya serta menangani kasus-kasus mengenai perilaku anak. Adapun alasan penentuan kualifikasi fasilitator tesebut, karena dianggap mengetahui tentang psikologi anak. Sebelum pelatihan dimulai fasilitator mendapatkan penjelasan tentang pelatian meningkatkan empati secara keseluruhan dan langkah-langkah penerapan modul pelatihan program meningkatkan empati di sekolah. Pembekalan fasilitator dilakukan pada tanggal 17 Februari 2016.

c. Memberikan informed consent. Peneliti selanjutnya memberikan informed consent kepada pihak sekolah sebagai penanggung jawab siswa yang terlibat penelitian ini. Peneliti kemudian menjelaskan secara lisan kepada kepala sekolah dan wali kelas mengenai pelatihan yang akan dilaksanakan.

d. Melakukan intervensi berupa pelatihan meningkatkan empati pada subjek penelitian. Pelatihan meningkatkan empati berlangsung selama 3 kali pertemuan dengan metode ceramah, diskusi, roleplay, story telling, games, tanya jawab dan tugas individu. Pertemuan pertama dilaksanakan pada tanggal 19 Febuari 2016, pertemuan kedua dilaksanakan pada tanggal 22 Februari 2016, pertemuan ketigas dilasakanakan pada tanggal 23 Februari 2016.

e. Melakukan pascates pada subjek penelitian pada tanggal 24-26 Februari 2016 dengan memberi skala dan mengobservasi kembali perilaku bullying dan empati siswa dengan prosedur yang sama sebagaimana pada pelaksanaan prates. Perilaku bullying dan empati siswa diobservasi selama 3 hari dengan 2 sesi pengamatan, pada tanggal 24-26 februari 2016. Setiap hari observer mengobservasi 1 sesi pengamatan pada 2 jam pelajaran yaitu 75 menit. Satu sesi pengamatan lagi dilakukan pada setting alami saat anak berinteraksi dengan temannya dilingkungan sekolah (Istirahat). Selain itu, peneliti melakukan wawancara kepada guru terkait perubahan perilaku subjek penelitian 
setelah mengikuti pelatihan meningkatkan empati.

f. Melakukan pengukuran tindak lanjut (follow-up) pada subjek penelitian yang dilakukan pada tanggal 07-10 Maret 2016 dengan prosedur yang sama sebagaimana pada pelaksanaan prates dan pascates.

\section{Metode Pengumpulan Data}

Alat ukur yang digunakan dalam penelitian ini adalah Peer Relations Questionnaire yang di susun oleh Sidorowics, dkk (2009) yang bertujuan untuk mengidentifikasi pelaku bullying. Selanjutnya skala perilaku bullying yang digunakan dalam penelitian ini disusun Kyriakides, L.dkk (2006) berdasarkan bentuk-bentuk bullying yang dikemukakan Olweus (2007) yaitu bentuk fisik, verbal dan indirect. Terdapat 8 aitem yang valid. Aitem valid mempunyai corrected item-total correlation bergerak dari 0.461 sampai 0.742 dan koefisien reliabilitas alpha $(\alpha)=$ 0.857 .

Skala empati yang digunakan dalam penelitian ini merupakan adaptasi alat ukur Davis Index Reaktif Antar Pribadi yang disingkat IRI yang digunakan pada anak- anak dari Garton dan Grigart (2005) berdasarkan pada aspek Kognitif dan Afektif. Terdapat 8 aitem yang valid dan 4 aitem yang tidak valid (gugur). Aitem valid mempunyai correcte aitem-total correlation bergerak dari 0.366 sampai 0.638 dan koefisien reliabilitas alpha $(\alpha)=0.755$. Penelitian ini menggunakan analisis statistik non-parametrik untuk uji hipotesis yaitu wilcoxon signed-rank.

\section{HASIL PENELITIAN}

Berdasarkan hasil perhitungan statistik nonparametrik skala bullying dengan analisis wilcoxon signed-rank diketahui bahwa ada perbedaan yang signifikan antara skor bullying sebelum dan setelah pelatihan meningkatkan empati. Hal ini diperoleh dari nilai $\mathrm{Z}=-2.207$ dengan $\mathrm{p}$ sebesar $0.027 \quad(\mathrm{p}<0.05)$. selanjutnya tidak ada perbedaan yang signifikan antara skor bullying setelah pelatihan dan follow-up (mean posttest $=11.88>$ mean follow$u p=9.88)$ dengan nilai ( $\mathrm{p}=0.058>0.05)$. selanjutnya ada perbedaan yang signifikan antara skor bullying sebelum (prates) dan dua minggu setelah pelatihan empati (tindak lanjut) (mean prates $=14.88>$ mean tindak lanjut=9.88) dengan nilai ( $\mathrm{p}=0.011>0.05)$.

Tabel. 1 Hasil Analisis Data Bullying Prates, Pascates, Tindak Lanjut

\begin{tabular}{lccc}
\hline Wilcoxon Signed Rank & $\mathbf{Z}$ & $\mathbf{p}$ & Keterangan \\
\hline Prates-Pascates & -2.207 & 0.027 & Signifikan \\
\hline Pascates-Tindak lanjut & -1.897 & 0.058 & Tidak signifikan \\
\hline Prates-Tindak lanjut & $-2,533$ & 0.011 & Signifikan \\
\hline
\end{tabular}

Hasil analisis data angket empati antara skor prates, pascates dan tindaklanjut dalam kelompok eksperimen menunjukkan bahwa ada perbedaan yang signifikan antara skor empati sebelum dan setelah pelatihan (mean pretest $=10<$ mean posttest $=16.13$ ) dengan nilai $(\mathrm{p}=0,012<0.05)$. Selanjutnya, tidak ada perbedaan yang signifikan antara skor empati setelah pelatihan dan follow-up (mean posttest=16.13<mean follow$u p=17.13)$ dengan nilai ( $p=0.146>0.05)$. Kemudian, ada perbedaan yang signifikan antara skor empati sebelum (prates) dan dua minggu setelah pelatihan empati (tindak lanjut) (mean prates $=10.00<$ mean tindak lanjut=17.13) dengan nilai $\mathrm{p}=0.011$ $(\mathrm{p}<0.05)$. Artinya pelatihan terbukti meningkatkan empati dan dapat 
mengurangi perilaku bullying pada siswa sekolah dasar. Namun Pelatihan meningkatkan empati ini perlu dilakukan setiap minggu untuk memperkuat empati siswa sehingga dapat mengurangi perilaku bullying secara konsisten.

Tabel. 2 Hasil Analisis Data Empati Prates, Pascates, Tindak Lanjut

\begin{tabular}{lccc}
\hline Wilcoxon Signed Rank & $\mathbf{Z}$ & $\mathbf{p}$ & Keterangan \\
\hline Prates-Pascates & -2.525 & 0.012 & Signifikan \\
\hline Pascates-Tindak lanjut & -1.452 & 0.146 & Tidak signifikan \\
\hline Prates-Tindak lanjut & -2.530 & 0.011 & Signifikan \\
\hline
\end{tabular}

Adapun hasil skor total pada setiap subskala menunjukkan bahwa terdapat perbedaan skor total perbandingan skor tingkat bullying pada kedelapan subjek penelitian setelah dan saat tindak lanjut perlakuan.

Tabel 3. Skor Total Bullying Pascates dan Tindak lanjut untuk Kedelapan Subjek

\begin{tabular}{lcccccccc}
\hline & HM & HN & AZ & ML & LF & DR & SA & AD \\
\hline Pascates & 18 & 22 & 13 & 11 & 11 & 13 & 1 & 6 \\
\hline Tindak lanjut & 18 & 14 & 10 & 10 & 8 & 11 & 2 & 6 \\
\hline Diff & 0 & 8 & 3 & 1 & 3 & 2 & -1 & 0 \\
\hline \multicolumn{7}{r}{ Keterangan: Diff $=$ perbedaan skor } \\
\end{tabular}

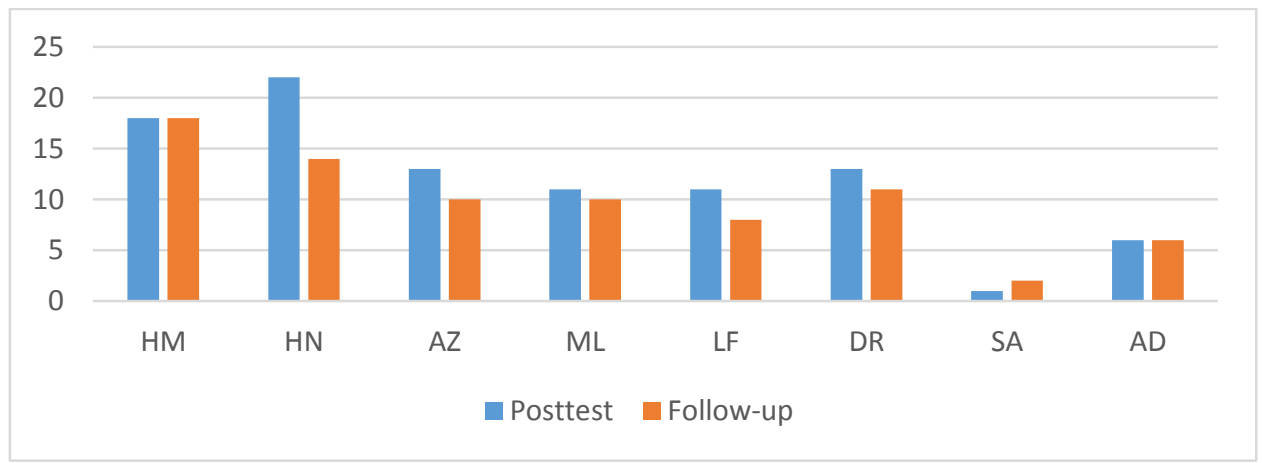

Grafik 1. Skor Total Bullying Pascates dan Tindak lanjut

\section{PEMBAHASAN}

Penelitian ini bertujuan untuk mengetahui pengaruh pelatihan meningkatkan empati untuk mengurangi perilaku bullying pada pelaku bullying. Selain itu juga untuk mengetahui perbedaan tingkat perilaku bullying dan empati sebelum (prates), setelah (pascates) diberikan pelatihan meningkatkan empati dan tindak lanjut pada kelompok eksperimen.

Untuk menguji hipotesis penelitian, dilakukan analisa statistik dengan menggunakan data hasil pengukuran skor empati dan bullying subjek penelitian sebelum, setelah mengikuti program pelatihan empati dan tindak lanjut.. Berdasarkan hasil analisis data angket bullying prates dan pascates diperoleh nilai Z sebesar -2.207 dengan p sebesar 0.027 $(\mathrm{p}<0.05)$ yang berarti signifikan, namun pada pascates dan tindak lanjut data bullying diperoleh nilai $\mathrm{Z}$ sebesar -1.897 dengan $\mathrm{p}$ sebesar 0.058 ( $p>0.05)$ yang berarti tidak signifikan dan hasil prates dan tindak lanjut diperoleh nilai $\mathrm{Z}$ sebesar -2.533 dengan $\mathrm{p}$ 
sebesar $0.011 \quad(\mathrm{p}<0.05) \quad$ yang berarti signifikan.

Hasil penelitian yang diperoleh menunjukkan bahwa ada perbedaan yang sangat signifikan antara sebelum (prates) mendapatkan perlakukan pelatihan meningkatkan empati dengan sesudah pelatihan, dimana setelah mendapatkan perlakukan pelatihan meningkatkan empati, tingkat perilaku bullying lebih rendah dibandingkan sebelum mendapatkan perlakuan. Kemudian, tidak ada perbedaan yang signifikan antara setelah (pascates) mendapatkan perlakuan pelatihan meningkatkan empati dan setelah dua minggu (tindak lanjut) mendapatkan perlakuan. Namun, uji beda antara prates dengan tindaklanjut terbukti adanya perbedaan yang signifikan. Pada penelitian dengan desain A-B-A besarnya pengaruh dari suatu perlakuan (intervensi) terhadap variabel tertentu sudah cukup dapat dilihat dari satu kelompok (eksperimen) (Sunanto, dkk, 2005).

Elliot (2002) mengatakan karakteristik perilaku bullying, salah satu diantaranya yang menduduki urutan teratas adalah agresif ke orang lain., lemahnya kontrol impuls dalam diri dan menilai positif terhadap kekerasan. Jika dikaitkan dengan data temuan dalam penelitian ini dimana subjek mengakui bahwa mereka melakukan tindakan bullying kepada teman mereka di sekolah. Tindakan bulllying yang dilakukan ialah bullying verbal, bullying fisik dan bullying psikologis. Semua subjek dalam penelitian ini juga mengatakan bahwa mereka menikmati dan senang saat membully temannya, mereka menganggap membully adalah hal yang biasa. Hal ini sejalan dengan pendapat yang disampaikan Elliot di atas bahwa mereka menilai positif terhadap kekerasan. Salah satu faktor yang menyebabkan perilaku bullying pada pelaku adalah adanya faktor kepribadian (Koeswara, 1998). Empati sebagai bagian dari karakteristik seseorang yang diduga menjadi penyebab terjadinya bullying (Mawarni, dkk 2011). Salah satu cara untuk mengurangi bullying dalam penelitian ini adalah memberikan intervensi berupa pelatihan empati kepada pelaku

Pelatihan empati merupakan metode pembelajaran yang dirancang untuk mengurangi perilaku bullying pada siswa sekolah dasar. Hasil penelitian ini sekaligus mendukung hasil penelitian sebelumnya tentang program membangun empati. Pelatihan meningkatkan empati mengajarkan tentang keterampilan empati pada anak sekolah dasar sehingga anak dapat mengerti dan menempatkan diri pada kondisi orang lain dengan tepat seperti yang dirasakan orang lain (Daruma, 2003; Perrault, 2009) serta lebih mengerti bagaimana bersikap empati kepada orang lain agar tidak melakukan bullying. Pelatihan mengenai meningkatkan empati juga dilakukan Sari (2015) hasilnya terdapat perbedaan nilai sebelum dan sesudah pelatihan yang artinya program pelatihan peningkatan empati memberikan dampak terhadap peningkatan empati siswa yang melakukan bullying di sekolah.

Berdasarkan hasil penelitian-penelitian terdahulu maka hasil penelitian ini membuktikan bahwa pelatihan meningkatkan empati dapat menurunkan perilaku bullying dan meningkatkan empati pada siswa pelaku bullying SDIT "X" Yogyakarta.

Creemers dan Reezigt (1999) menyebutkan salah satu faktor yang dapat mempengaruhi perilaku anak adalah faktor keefektifan, baik faktor keefektifan sekolah maupun kelas yang terdiri atas kualitas belajar, waktu untuk belajar dan kesempatan untuk belajar. Penjelasan lebih lanjut bahwa perilaku bullying lebih sering terjadi pada anak laki-laki dengan stereotip tradisional (Pepler et al., 2006). Dengan demikian anak laki-laki lebih sering melakukan perilaku bullying untuk mempertahankan citra laki-laki mereka 
sehingga pelatihan meningkatkan empati ini tidak bertahan lama pada subjek penelitian, pada saat tindak lanjut tidak terjadi perubahan yang signifikan, namun jika dilihat dari skor dan kategori masing-masing subjek terjadi penurunan tingkat bullying dan peningkatan empati dan pada kategori yang sama. Hal ini menunjukkan bahwa ada faktor lain yang mempengaruhi perilaku bullying di luar individu, yaitu keluarga, faktor teman sebaya dan faktor sekolah (Center for the Sctudy and Prevention of School Violence, 2008). Selanjutnya hasil penelitian Sari (2015) adanya perbedaan skor sebelum dan sesudah intervensi menunjukkan adanya kemampuan empati yang meningkat.

Setelah mengikuti pelatihan dan mendapatkan pemahaman mengenai empati, para subjek berusaha mengaplikasikannya dalam kehidupan sehari-hari terutama di sekolah. Fokus utama dalam penelitian ini ialah menurunnya perilaku membully dari seluruh subjek yang mengikuti pelatihan meningkatkan empati. Dengan berdasarkan wawancara kepada guru, kedelapan subjek penelitian berusaha untuk tidak melakukan bullying kepada temannya dengan berusaha mengontrol diri untuk tidak mudah terbawa emosi. Mereka juga mengisi buku kontrol yang ditanda tangani oleh guru wali kelas sebagai upaya peningkatan empati subjek. Empati yang meningkat juga ditunjukkan dengan subjek yang sudah mau menolong temannya jika sedang menjadi korban bullying atau teman yang sedang mengalami kesulitan.

Aspek kognitif empati yaitu kemampuan intelektual untuk mengidentifikasikan dan mengenali perasaan orang lain (Eisenberg dan Moris, 2001; Hunter 2003) terbukti dapat terlihat dari ungkapan subjek dalam self report yang menulis berbagai perasaan ketika ia menjadi orang lain. Anak dapat mengenali kalau diganggu dan diejek rasanya sedih, dapat mengatakan kalau jadi orang yang dibully itu rasanya ingin marah dan sedih. Begitu juga dalam setting sekolah jika anak dijauhi teman maka tidak nyaman dan sedih serta guru tidak akan nyaman jika melihat muridnya nakal dan sulit diatur.

Selain aspek kognitif, peningkatan aspek afektif yang merupakan kemampuan untuk mengalami dan berbagi perasaan dengan orang lain ditunjukkan oleh anak (Eisenberg \&Moris, 2001). Anak merasakan bagaimana rasanya menjadi orang yang selalu diejek, didorong, dipukul (victim). Anak merasakan jengkelnya guru bila anak didiknya sulit diatur dan nakal. Merasakan perasaan teman yang sakit atau yang membutuhkan pertolongan kerena jatuh dan tidak bisa ikut bermain, atau merasakan perasaan teman yang orang tuanya meninggal.

Dengan demikian, empati memiliki kaitan dengan perilaku bullying, dimana semakin tinggi level empati seseorang maka semakin kecil kemungkinan seseorang tersebut menjadi pelaku bullying. Hal ini dikuatkan oleh teori yang dikemukakan Jolliffe dan Farrington (2006) dimana empati erat kaitannya dengan perilaku prososial (perilaku menolong).

\section{KESIMPULAN DAN SARAN}

Berdasarkan hasil penelitian dan pembahasan yang telah dikemukakan, maka dapat disimpulkan bahwa Pelatihan meningkatkan empati dalam penelitian ini dapat mengurangi perilaku bullying pada pelaku bullying sekolah dasar. Melihat dampak positif dari pelatihan meningkatkan empati, maka diharapkan pelatihan ini dapat terus diimplementasikan dan dikembangkan di Sekoah Dasar. Khususnya di SDIT tempat penelitian ini dilaksanakan. Diharapkan pihak Sekolah dapat bekerjasama dengan lingkungan keluarga, terutama orang tua dalam mencegah perilaku bullying ini. Guru diharapkan berperan aktif dalam mencegah terjadinya tindakan bullying di sekolah, memberi 
contoh yang baik, mengurangi tindakan kekerasan sebagai hukuman, memberi informasi tentang tontonan kepada siswa/siswi. Bagi orang tua diharapkan membimbing anak dengan pengajaran dan teladan serta tidak membiarkan anak melakukan sesuatu tanpa pengawasan orang tua seperti penggunaan media elektronik dan media massa. Bagi peneliti selanjutnya dapat menerapkan perlakuan pada semua pihak seperti lingkungan keluarga dan lingkungan sekolah sehingga dampak menurunnya perilaku bullying akan lebi maksimal.

\section{DAFT AR PUST AKA}

Baron, R. A., \& Byrne, D. (2005). Psikologi Sosial (Jilid 2 Edisi Kesepuluh Alih Bahasa Ratna Djuwita). Jakarta: Erlangga.

Center for the Study and Prevention of School Violence (2008). Safe SchoolsSafe Communities: Fact Sheet. Institute of Behavioral Science. Boulder: University of Colorado.

Creemers, B. P. M., \& Reezight, G. J. (1999). The role of school and classroom climate in elementary school learning environments. Philadelphia: Falmer Press.

Daruma, H. A, R. (2003). Empati dan Pribadi yang Unggul. Jurnal Intelektual, 1 (1), 103-114.

Efianingrum, A. 2009. Pengembangan Model Pelatihan Respect bagi Guru untuk Mencegah Kekerasan di Sekolah Dasar. Lemlit UNY: Laporan Penelitian.

Eisenberg, N \& Mussen, P.H. (1989). The Roots of Prosocial Behavior Children. New York. Cambridge University Press.

Eisenberg, N \& Strayer, N. (1987) Empathy and Its Development. Cambridge: Cambridge University Press.
Eisenberg, N., et al. (2002). Prosocial Development in Early Adulthood: Longitudinal Study. Journal of Personality and Social Psychology, 82(6).993-1005.

Eisenberg. N., \& Morris, A. S. (2001). The Origins and social significance of empathy-related responding. A review of empathy and moral development: Implications for caring and justice by M.L. Hoffman. Social Justice Research, 14,95-120.doi:0885-7466/01/03000095/0

Elliot, M (ed). (2008). Bullying A Practical Guide to Coping for Schools, $3^{\text {rd }}$ Edition. London: Pearson education in Association with Kidscape.

Garton, A.F., \& Gringart, E. (2005). The Development of a Scale to Measure Empathy in 8- and 9-year old Children. Australian . 5. 17-25.

Hunter, K. R. (2003). Affective empathy in children: measurement and correlates. (Disertasi Doktor, School of applied psychology, Griffith University). Diakses dari http://www.ads.lib.ugm. ac.id 
Kyriakides, L., Kaloyirou, C., Lindsay, G. (2006). An Analysis of the Revised Olweus Bully/Victim Questionnaire Using the Rasch Measurement Model. British Journal of Educational Psychology. 76, 781-801.

Mawarni, R., Hardjono., Andayani, T. R., (2011). Hubungan Antara Mencari Sensasi dan Empati dengan School Bullying pada Remaja Putra kelas X dan XI di Madrasah Mu'allimin Muhammadiyah Yogyakarta. Naskah Publikasi. Program Studi Psikologi. Fakultas Kedokteran. Univeristas Sebelas Maret.
Sari, H. N. (2015). Pelatihan Meningkatkan Empati Melalui Psikoedukasi kepada Pelaku Bullying sebagai Upaya untuk Mengurangi Bullying di Sekolah Menengah Pertama. Tesis. (Tidak Diterbitkan). Magistes Psikologi Profesi. Fakultas Psikologi. Univeristas Padjadjaran.

Smith, P. K., Pepler, D., \& Rigby, K. (2007). Bullying in School: How successfull caninterventions be?, di unduh 27 Januari 2012, dari www.cambridge.org

Sunanto, J., Takeuchi, K., \& Nakata, H. (2005). Pengantar penelitian dengan subjek tungal. University of Tsukuba: Center for Research on International Cooperation in Educational Development (CEIGED). 
Lailatul Izzah, Sukarti \& Uly Gusniarti 